\title{
Aile Ev Dergisi ve Biyopolitika (1947-1952)
}

Sevim Odabaş

\section{Öz}

Bu yazı Türkiye'de biyopolitik mevzuların konuşulduğu kamusal metinlerden Aile Ev Dergisine odaklanmaktadır. Bu yazıda 1947-1952 yılları arasında aile, evlilik, kadınl1k, çocukluk ve yaşam hakkında kamusal metin üreten Aile Ev Dergisinin monografisi sunulmaya çalışılmaktadır. Bu dergideki yazılar yahut kamusal metinler dönemin biyopolitik kaideleri ve mücadeleleri hakkında önemli noktalara dikkat çekmektedir. Didaktik, pedagojik bir üslupla okuyucularına modern hayat tarzı hakkında nasihatler vermektedir. Türkiye'de yurttaşların sahip olması gereken biyopolitik vasıflara işaret etmektedir.

Anahtar Kelimeler: Biyopolitika mevzuları, aile, evlilik, kadınlık, çocukluk.

* Dr. Öğr. Üyesi, Mersin Üniversitesi Fen - Edebiyat Fakültesi Sosyoloji Bölümü, Mersin/Türkiye, sodabas@mersin.edu.tr, orcid.org/0000-0001-6145-2869 


\title{
Family Home Magazine and Biopolitics (1947-1952)
}

\begin{abstract}
This study focuses on Family Home Magazine, one of the public texts in which biopolitics issues are discussed. The study aims to present the monograph of Family Home Magazine produced public texts about family, marriage, womanhood, childhood and life between the years of 1947-1952. Articles or public texts in the magazine draw attention to the important points about biopolitics principles and struggles of the age. The magazine gives advices on modern lifestyle to its readers in a didactic and pedagogic way. It points out biopolitical qualifications that Turkish citizens must have.
\end{abstract}

Keywords: Biopolitics issues, family, marriage, womanhood, childhood. 


\section{Giriş}

Bu yazı, Yapı Kredi Bankasının 1947-1952 yılları arasında ikramiyeli aile cüzdanı sahibi olanlara armağan olarak hazırladığı, banka şubesi olmayan yerlere posta ile gönderdiği ve serbest satışa az miktarda çıkardığ 1 Aile Ev Dergisinde yer alan biyopolitika mevzularına odaklanmaktadır. Bir başka deyişle, Aile Ev Dergisinden hareketle dönemin söz dağarcığında yer alan aile, kadın, evlilik, çocuk, yaşam vb. biyopolitika mevzularındaki içeriğe, kodlara ve ölçülere bakmaktadır. $\mathrm{Bu}$ inceleme kapsamında 1947-1952 y1lları arasında 20 say1 yayımlanan ve kitlelere seslenen Aile Ev Dergisine çözümleme kaynağ 1 olarak başvurulmakta ve içeriği gözler önüne serilmektedir.

Aile dergisini Vedat Nedim Tör hazırlamaktadır. Dergide, Yahya Kemal, Refik Halid Karay, Ahmet Hamdi Tanpınar, Halide Edip Adıvar gibi dönemin ünlü edebiyatçıları ve ilim adamları kitleleri aydınlatmak için yazılar yazmaktadır. Ayrıca, dergide Amerikan dergilerinden yapılan çeşitli tercüme yazılara da yer verilmektedir. Aile dergisinde dönemin zihniyet dünyasını ve kodlarını görmek mümkündür. Vedat Nedim Tör, ilk sayıda Aileyi Kurarken adlı önsözünde Türk ailesinin huzura ve sükûna ihtiyacının olduğunu dile getirir. Ona göre bütün kıtl1k ekonomisi memleketlerinde olduğu gibi bizde de aile, düşük verimli bir iş tekniği, kötü organize bir iş hayatı yüzünden yıpratıcı bir geçim kavgası içindedir. Bundan ötürüdür ki, "umumiyetle sinirlerimiz bozuk, suratlarımız asık, muaşeret hayatımız sert ve kırıcıdır. Bunu aile hayatımızda olduğu gibi iş ve politika hayatımızda da müşahede edegelmekteyiz. Yaşama sanatının acemisi olduğumuz için çabuk ihtiyarlıyor ve çabuk verimsizleşiyoruz. Yaşama sanatının en büyük sırlarından biri dinlenmektir. Dinlenmenin en iyi yollarından biri de okumaktır. Aile dergisi dinlenme ihtiyacını en zevkli ve faydalı bir tarzda doyurmak için çıkıyor. Bu dergi, zevkinizi yükselterek, sinirlerinizi rahatlatacak ve yaşama şevkinizi canlandıracaktır"1. Aile dergisinde hikâyeler, edebi yazılar dışında ailenin gündelik hayatı ve yaşama sanatı ile ilgili konular üzerinde durulmaktadır. Bunlar, dergi okuyucularına aktarılmaktadır. Dergide ailenin sağlığı, ailenin mutfağ1, ailenin röportajları, ailenin modası, ailenin müsabakası vb. adlı köşelerde çeşitli konular işlenmekte ve aile hayatı ile ilgili çeşitli noktalara parmak basılmaktadır.

\section{Biyopolitika Mevzuları}

Biyopolitika, çıplak hayatımızın yahut doğuştan getirdiğimiz statümüzün haklar, sorumluluklar, kaideler, istisnalar eşliğinde yeniden üretilmesi, yapılandırılması ve denetlenmesidir. Biyopolitika çıplak hayat ve onunla ilgili doğum,

Vedat Nedim Tör, “Aileyi Kurarken”, Aile Ev Dergisi, say1 1, 1947, s.1. 
cinsellik, evlilik, kadınlık, erkeklik, çocukluk, gençlik, yaşlılık, yaşam ve ölüm vs. olguları makro ve mikro düzeyde tesis eden her türlü tahayyül, tanım, eylem, tasarruf, yasa, direniş ve sınır ağlarıdır. Biyopolitika hayat üzerindeki denetimin yoğunlaşıp genişlemesi ve hayatın toplumsal mücadelelerin merkezi haline gelmesidir. ${ }^{2}$ Biyopolitik mücadeleler hayatın, evliliğin, ailenin, kadınlığın, erkekliğin, çocukluğun, gençliğin, neslin vs. nasıl olması gerektiği üzerinde yürütülen mücadelelerdir. Bunlar, hayat tarzlarını, benlikleri, tahayyül ve eylem alanlarını yapılandıran temel mücadelelerdir. Biyopolitika hakkında konuşmak aslında hayat ve onunla ilgili olgular hakkında kimin nasıl konuştuğu, iktidar kurduğu ve bir bedensel topluluğa, düzene dâhil olmanın yahut bu düzenden dışlanmanın tanımları ve ölçülerinin neler olduğu hakkında da konuşmaktır. Şimdi Aile dergisinde konuşulan biyopolitik mevzuların içeriğini ana hatları ile gözler önüne sermeye çalışalım.

\section{Aile Mevzusu ve Siyaseti}

Aile dergisinde, toplumda meydana gelen değişmelerin aile anlayışında ve aile ilişkilerindeki yansımalarını konu edinen yazılara yer verilir. Nasıl bir aile siyaseti izlenmesi gerektiği ile ilgili çeşitli öneriler sunulur. 1947 yılının ilk sayısında Mustafa Şekip Tunç, Eski Aileden Yeni Aileye adlı yazısında toplumsal değişmeye bağlı olarak aile anlayışında meydana gelen değişmelerden bahseder. Tunç'a göre her şeyden evvel yeni ailenin içinde yaşadığ 1 kültür havası artık ortaçağın havası değildir ve olamaz. Yeni ailedeki inzibat ve itaat, herhalde mutlakiyetin istediği şekilde olmayacak, ferdiyet ve hürriyet şuurlarından doğan kuvvetli bir haysiyet hassasiyetine dikkat etmek lazım gelecektir. Aile efradı arasındaki münasebet ve mertebelerin ruhu değişecektir. Yeni aile, eski aile gibi, evin en büyük erkeğinde mutlak bir otorite ve hakimiyetin tabii görüldüğü bir aile değildir. Sadece karı koca ailesidir. Kaynana ve kaynataların bu ailenin içinde yaşamaktan ziyade dışında yaşamaları lâzımdır. Otorite ve hâkimiyetlerini yetişmiş, ev kurmuş ve onun her türlü vazife ve mesuliyetlerini yüklenmiş olan evlatlarına mutlak olarak yürütmek hakkına da artık sahip değillerdir. Nüfuz ve tesirlerini ancak kâmil, mülâyım yol göstermeler ve yerinde nasihatlerle takviye edebilirler. Manevi mahiyette olan bu mühim noktalardan başka maddi hayatın da yeni ailenin huzur ve selâmetindeki rolü artık sadece kanaat ve açık ellilik olmaktan ziyade hesaplı, ölçülü ekonomik bir çalışkanlık zihniyeti olmak lâzım geliyor.

2 Bkz.,Michel Foucault, Cinselliğin Tarihi, Çev. H.U.Tanrı̈ver, İstanbul: Ayrıntı Yayınları, 2012. Giorgio Agamben, Kutsal İnsan: Egemen İktidar ve Çıplak Hayat, Çev. İ.Türkmen, İstanbul: Ayrıntı Yayınları, 2001. Thomas, Lemke, Biyopolitika, Çev. U. Özmakas, İstanbul: İletişim Yayınları, 2013. 
Çünkü kaza ve kaderini daha çok kendi gücü, kendi zekâsı, kendi karakterinden beklemek mecburiyetinde olduğu bir kültür hayatı ve ekonomik düzeninin havası içinde yaşamaktadır. Yeni ailede erkek otoritesi güneş 1şınları gibi hiç ağırlık vermez bir halde olmalı, kadın da en çok ışınlarla 1sınıp parlamaktan mesut olacağını bilmelidir. $^{3}$

1947 yılının ikinci sayısında Vâlâ Nureddin, okuyuculara Mesleğiniz Dışında Neye Merakınız Var? diyerek seslenir. Nureddin yazısında, amatörlüğü aile maneviyatının ve ahlâkının temel direği olarak tanıtır ve ele alır. Amatörlügüu, bir tek mevzua heveslenip, kendi kazanç mesleği dışındaki o işi, diğer insanlardan daha ileriye götürmek yahut hususi istikamete çevirmek olarak görür. Nureddin mütareke sıralarında İstanbul'a Vrangel ordusunun bakiyelerinin döküldüğünden söz eder. Nureddin'e göre bunların İstanbul'da kalburüstü kalmalarında, gittikleri Avrupa ve Amerika memleketlerinde sefalete düşmemelerinin başlica sebebi, beraberlerindeki küçük çantalar içinde kaçırdıkları mücevherler değildi. Zira çoğunun mücevheri yoktu ama "altın bileziği”" vardı. Hukukçuluğun, heykelciliğin, askerliğin, idareciliğin dışında kimi müzik, kimi resim, kimi oymacılık, kimi aşçılık biliyordu. Zamanlarında bir modaya uyarak memleketlerindeki bu amatörlükleri edinmişlerdi. Yıkılan hayatlarını o sayede kurdular. Yalnız muhacerette değil iktisadî felâketlerde bu böyle. Amatörlük aile maneviyatının, ahlâkının temel direğidir dense hata olmaz. Düşünülsün ki bizde milli egemenliğin ilerlemesi sayesinde ekseri aile kadınları orta, lise hatta bazen yüksek tahsillerini yapmış bulunuyor. Şayet müreffeh bir izdivaç yaparlarsa çalışmağa ne hacet? Bay işe giriyor. Bayan evde... Böyle bir vaziyet karşısında felâketlere karşı sigorta yine amatörlüktür. Yuvasını kaza ve belâlardan korumak isteyen kendini de eşini de çocuklarını da amatörlüklerle sigortalamalıdır. Boş zaman yeşil çuhalı masa başında geçmez. Dedikoduyla, gıybetle, esnemekle, can sıkıntısı yüzünden işretle kıskançlık kavgasıyla geçmez. Hele karı koca aynı amatörlükte birleşirlerse dostlukları artar. Ayrılamaz arkadaşlar halini alırlar. Çocuklarına da ailedeki ve muhitteki avarelere de pek güzel misaller teşkil ederler. Hele çocuklar için ailedeki amatörlük iksirdir. İhtimal çocuk hakiki yüksek istidadını, müstakbel mesleğini baba ananın amatörlükleri arasında bulacaktır. ${ }^{4}$

Ailenin sağllğ̣ köşesinde hekim İhsan Şükrü Aksel, Evde Sinir Muvazenesi adlı yazısında aile yuvasının devletin kurulmasını sağlayan bir parça olduğuna ve onun sağlam esaslara dayanmasının devleti de kuvvetlendirdiğine işaret eder.

3 Mustafa Şekip Tunç, "Eski Aileden Yeni Aileye”, Aile Ev Dergisi, sayı 1,1947, s.12-4.

4 Vâlâ Nureddin, "Mesleğiniz Dışında Neye Merakınız Var ?”, Aile Ev Dergisi, sayı 2, 1947, s. 23-4. 
Aksel, aile psikolojisindeki ahengin devlet mekanizmasındaki ahengin de esasını teşkil edeceğini ileri sürer. Ona göre bugünkü sosyal durum büyük şehirlerde cinsî ihtiyaçların çok kolaylıkla tatmin edilmesine imkân vermektedir. Böylece aile kurulması ve onun devamı meselesinde cinsî arzuların tesiri kıymetini kaybetmektedir. Eskiden din terbiyesi, Allah korkusu aile yıkılmalarını önleyebiliyordu. Son zamanlarda bunların yerini daha ziyade iyi soy ve çocuk yetiştirme, evlat sevgisi, nihayet karı koca arasında doğan ve kuvvetlenen can yoldaşlı̆̆ arkadaşlık sevgisi almış bulunmaktadır. Ailede geçimsizliklerin sebepleri pek çoktur. Ruhî âmiller arasında kültür ve seviye farkı, cinsi hayatta anlaşamamak başta gelenlerindendir. Buna gelin-kaynana, gelin-görümce çatışmalarını da ilave etmek gerekir. Ailenin ruhi bünyesini sarsan sebeplerden biri de bizdeki terbiye sistemlerinin değişikliğidir. Eski din terbiyesinin yerini alması icabeden millî terbiye henüz tamamen kökleşmemiştir. Bu bakımdan aynı seviyeden gibi görünen karı kocanın pek ayrı terbiye aldıkları vaki oluyor ki, bu kadar zit zihniyetteki insanları aile çevresi içinde devamlı olarak tutmak çok zorlaşıyor. Burada kadın erkek hâkimiyeti meselesi de işe karışıyor. Eskiden ailelerde erkek yegâne hâkimdi. Şimdi kadınlar da hayat işlerini erkeklere yakın şekilde paylaştıklarından ve aralarında kültür farkı pek kalmadığından ailede hâkimiyet mücadelesi de ortaya çıkmış oluyor. Bu kadar dolambaçlı bir duruma giren aile psikolojisinin selâmetini sağlamak bir hayli güçleşmiştir. Bütün bu zorlukları yenebilmek, ailenin devamını sağlayabilmek için son zamanlarda bazı Avrupa memleketlerinde evliliği koruma teşekkülleri kurulmaktadır. Bu bürolar, mütehassıs hekimlerin idaresine bırakılmakta, geçimsizlikten ayrılmaya kalkışan aileler bir kere de bu hekimlerin önünde dertlerini dökmekte, anlaşmanın ruhî imkânları araştırılmaktadır. ${ }^{5}$

Derginin dördüncü sayısında İstanbul Üniversitesi profesörlerinden Gerhard Kessler Aile Siyaseti yazısında ailenin mukaddesliği hakkında güzel nutuklar söylenmesine rağmen aile siyasetini başlıca politik vazifeler arasında kabul eden ve gerçekleştirmeye çalışan memleketlerin çok az olduğunu söyler. Kessler'e göre bir ailenin sıhhî bir hayat sağlayabilmesinin esası sıhhî bir aile yuvasına yahut evine sahip olmasıdır. Ümitsizlik içinde kalan aile reisleri geceleri "gecekondu" tabir edilen binlerce baraka inşasına teşebbüs ettikleri bir şehirde, binlerce ailenin evden mahrum olduğu anlaşılır. Şu halde görülüyor ki, burada derhal küçük aile evlerinin inşası ilk ve önemli vazifeyi teşkil etmektedir. Bütün diğer inşaat planları ikinci derecede kalmalıdır. İhtiyaca kâfi gelecek sayıdaki sıhhî küçük aile evlerinin ehemmiyeti karşısında spor sarayları, stadyumlar, sergi binaları, tiyatrolar, gazino vs. hiç bir kıymet ifade etmez. Ayrıca, bir anne daima surette evinin dışın- 
da çalışır, kendini tamamıyla çocuklarına vermezse o aile yıkılmaya mahkûmdur. Eğer aile siyaseti güdülmek isteniyorsa ailenin her türlü tıbbî muayene ve tedaviden faydalanacağı hastalık sigortaları şehirlerde olduğu kadar köylerde de tesis edilmelidir. Fiyat politikası da aile siyasetine dâhildir. Ailelerin sıhhatli olmaları ve sıhhatli kalmaları arzu ediliyorsa ekmek, et, yumurta, yemiş ve sebze fiyatları mümkün olduğu kadar ucuz, buna mukabil bira ve rakı fiyatları mümkün olduğu kadar pahalı tesbit edilmelidir. İleri görüşlü bir aile siyasetinin çerçevesine dâhil olan daha bir çok şeyler sayabiliriz. Şimdilik bütün şehir çocuklarının istifade etmeleri gereken oyun sahaları ve deniz banyoları ile şehirdeki bütün ailelerin pazar ve tatil günlerinde faydalanacakları parklar ve ormanlar bunlar arasındadır. ${ }^{6}$

Aynı sayıda İstanbul Üniversitesi Profesörlerinden F. Neumark da Mesken Meselesi ve Aile yazısında mesken ihtiyacının, beslenme ve giyinme ile insanın en önemli ve zaruri ihtiyaçları arasında yer aldığına dikkat çeker. Neumark, mesken ihtiyacının tatmin tarzının iktisadî ve içtimaî faktörlere bağlı olduğunu dile getirir. Mesken ihtiyacının tatmin tarzında bir memleketin refah seviyesi ve milli gelirinin bölünme şeklinin etkili olduğunu vurgular. Neumark, bir millet için mesken yapı işleri bilhassa ekonomi ve sağlık bakımlarından büyük bir önemi olduğunu söyler. Ona göre, şayanı şükrandır ki, Türkiye harbin yıkıcı tesir ve neticelerinden bu sefer korunabilmiştir. Bununla beraber bizde bir mesken meselesinin, daha doğrusu bir mesken buhran ve davasının mevcut olduğu inkâr edilemez bir gerçektir. Bu davanın halline gelince, aile hayatının en önemli esaslarından birini teşkil eden meskenin büyük sosyal, ekonomik ve hatta siyasî ehemmiyeti nazarı dikkate alınacak olursa devletin bu davaya karşı lâkayt kalamayacağı aşikârdır. Devlete düşen vazife daha ziyade hususi ev ve apartman inşaatına engel olan idari ve mali güçlükleri ortadan kaldırmak, yapı malzeme fiyatlarını ucuzlatmak ve bir kaç sene zarfında kendi yapılarını mümkün mertebe tehir etmekten ibarettir. ${ }^{7}$

Şevket Rado, Ayıran ve Birleştiren Kitap yazısında büyük şehirlerdeki karı koca geçimsizliklerinde kitabın esaslı bir yeri olduğunu dile getirir. Rado'ya göre, kitabı sevenle sevmeyen arasındaki uçurum ne kadar derin olursa olsun, okumayı bilen ile bilmeyen arasındaki uçurum kadar derin ve korkunç değildir. Ailedeki tatsızlıkların bir kısmı okumayı bilen karı-kocanın kitabı aynı ölçüde sevmemelerinden geliyorsa milletleri teşkil eden fertler arasındaki anlaşmazlıkların en büyük kısmı da okumayı bilmeyenlerin çokluğundan doğuyor. Okumamışın okuyanı "yaban" sayması, okuyanın okumamışı bütün isteğine rağmen bağrına basamaması başka ne ile izah edilebilir? Kitabın arada bir ocak yıktığına

6 Gerhard Kessler, “Aile Siyaseti”, Aile Ev Dergisi, say1 4, 1948, s. 9-10.

7 F. Neumark, "Mesken Meselesi ve Aile", Aile Ev Dergisi, say1 4, 1948, s 17-9 
bakmayalım. Karı-koca gibi bir milletin fertlerini de birbirine yaklaştıracak olan şey eninde sonunda yine kitaptır. ${ }^{8}$

Vedat Nedim Tör Okuyan Aile yazısında, severek yaptıkları bir "merak"lar1 olmayan, yani kendi kendilerini oyalamasını bilmeyen karı-kocaların zamanla birbirlerini yemeye mahkûm olduklarını söyler. Tör'e göre okumak bu gibi merakların hiç şüphesiz en asilidir. Okuyan insan rahatına düşkündür. Onun hır gür ve vır-vırla kaybedecek vakti yoktur. Kitabına, dergisine, gazetesine dalmış adam huzurun ta kendisidir. O, etrafina da dinlendirici, sessizliğe davet edici bir sulh havası yayar. Okuyan insanın adale ve sinirleri tam bir gevşekliğe kavuşur. Okumanın verdiği heyecanda bile bir sinirlenme halinin katılaşması ve gerilmesi değil, bir aşk ve vecd anının ruhu yükselten, aydınlatan tılsımı vardır. Okumak alışkanlığının insana verdiği bu ruh disiplinidir ki, ailenin muvazenesini korur. Aile içindeki geçimsizlikler, çatışmalar daha çok can sıkıntısından doğar. Kitap, ailede ahengin ve huzurun sigortasıdır. Bir kitaplığı olmayan ailelerin bahtiyarlığ 1 daima tehlikededir. ${ }^{9}$

\section{Kadın, Evlilik Mevzusu ve Siyaseti}

Aile dergisinde işlenen biyopolitik mevzulardan bir diğeri kadın ve evlilik mevzusudur. Evlilik hayatının gündelik saadetlerini küçük küçük şeylerin zehirlediğini konu edinen Eşref Saatini Kollayınız adlı yazıda, evli bir kadının sahip olması gereken vasıflar sıralanır. Bu yazıya göre, muhakkak ki her şeyin bir zamanı vardır. Yapılacak işin veya söylenecek sözün tam sırasını yani eşref saatini keşfetmeyi bilmek başlı başına bir hünerdir. Kadının işten dönen kocasına şu veya bu haberi vermenin sırası olmadığını sezecek kadar halden anlaması icap eder. Bir kadın ne kadar meziyetli olursa olsun biraz halden anlamıyorsa, bir şey söyleyeceği zaman "eşref saatini beklemeyi bilmiyorsa" karı da koca da evlilik hayatının saadetini tadamayacaklardır. ${ }^{10}$

Tıp hekimi Prof. Dr.Tevfik Remzi Kazancigil, Kadın Hayatının Altı Merhalesi adlı yazısında normal şartlarda yaşamış beden vazifelerini, içtimai vazifelerini yapmış bir kadının sırf insan nevi bakımından bile erkekten daha mühim varlık olduğundan söz eder. Ona göre insan neslinin istikbalini korumak bakımından kadına yardım etmek, kadını kuvvetlendirmek, normal bir cemiyet ve aile hayatında ona yerini ve hakkını vermek lâzımdır. Kültürlü bir kadın, insanı derisi altındaki canavardan uzaklaştırabilir, onu “yumuşatabilir", cemiyet hayatının itidal

8 Şevket Rado, “Ayıran ve Birleştiren Kitap”, Aile Ev Dergisi, sayı 5,1948, s 15.

9 Vedat Nedim Tör, "Okuyan Aile”, Aile Ev Dergisi, sayı 10, 1949, s. 5.

10 Aile Ev Dergisi, "Eşref Saatini Kollayınız”, Aile Ev Dergisi, sayı 2: 1947, s. 46-7. 
ve temkinine doğru yürüterek ona yardım edebilir. Kadını cemiyet içinde bir amil olarak tanımak, tanırken de onu kendi bünyesinin, vazifesinin zıddı yollara sevk etmemek, anneliğin mukaddes hududu içinde onu cemiyetin maddi, manevi himaye ve saygısından faydalandırmak, istidadı olanlara her türlü salâhiyeti ve kendi kudretini deneme imkânını vermek lâzımdır. Kadının enerji ve şefkatini cemiyete mal etmenin yollarını bulmak gerekir. Böyle bir saygının ve hak tanımanın "tek gözlüklü, pantolonlu, pipolu gülünç feministlerle" hiç bir münasebeti yoktur. ${ }^{11}$

Derginin Ailenin Röportajları köşesinde Vâlâ Nureddin'in Prof.Dr. Mazhar Osman ile karı koca geçimsizliğinin sebepleri ile ilgili yaptığı mülâkata yer verilir. Mazhar Osman'a göre eskiden evlendirme hakkı hemen hemen ana babanın arzusuna bırakılmıştı. Sonra bu hak gençlerin kendilerine kaldı ve gitgide bir takım fetişler hâkim oldu. Erkekler izdivaçta fetişe çok ehemmiyet veriyor. Bir kadının gözleri, dişlerinin güzelliği, yanağının çukuru çok defa bir delikanlıyı cezbediyor. Manevi meziyetler şöyle dursun maddi kusurlar bile aranmıyor. Delikanlı izdivaca karar veriyor. Tabii, pek az zaman sonra fetişin cazibesi küçülüyor, kusurlar gittikçe büyüyor. Hasta bir mizaç evin lezzetini bozar. İsterik bir kadın, melânkolik bir erkek, karşısındaki ne kadar sabırlı olsa, ezâ verir. Sinirleri iyice etüd etmekle ve bu kusurları izale etmekle aradaki tatsızlık pekâlâ zail olabilir. Evlenirken kadın ve erkeğin mizaçlarının tetkiki ve bunların hayat ortaklığına elverişli olup olmadığının araştırılması faydalıdır. Bazı sert mizaçlar izdivaç hayatının sıcak muhitinde yumuşar, asabî görünen bir kadın izdivacından sonra pekâlâ sakinleşir. Aksi de varid olabilir. İzdivaçta cemiyetin ve insanlığın gayesi çocuk yetiştirmektir. Ortada çocuk olduktan sonra her iki tarafa tahammülden başka bir şey tavsiye edilmez. Çocuğu terbiye etmek için babalarla anneler zevklerinden, arzularından ve huzurlarından fedakârlık etmek zorundadırlar. Bugünkü izdivaç çocuk esası üzerine kurulmuştur. ${ }^{12}$

Halide Edib Adıvar, derginin sohbet köşesinde genç kızlara hitap eder. Adıvar, genç kızların herhangi sebeble olursa olsun hayat sahasında en ileri gelen kadın haklarına ve kuvvetlerine sahip olduklarından söz eder. Bu hak ve kuvvetin bir zerresini bile feda etmemelerini tembihler. Ona göre genç kızlar yarınki ailenin temelidir. Aile her zaman ve mekânda milletin ve dünyanın en güçlü modelidir. Kadın, sadece bütün zamanını aileye vermekle değil, aynı zamanda memleketin ve dünyanın aile denilen insan zümresinin maddi ve manevî ehemmiyet

11 Tevfik Remzi Kazancıgil, "Kadın Hayatının Altı Merhalesi”, Aile Ev Dergisi, sayı 3: 1947, s.17-9.

12 Vâlâ Nureddin, “Ailenin Röportajları: Kar1-Koca Geçimsizliğinin Tedavisi Mümkün Müdür?”, Aile Ev Dergisi, say1 3, 1947, s.20-3. 
ve haklarını koruyabilecek, kuvvet ve hakka malik olması lâzımdır. Her genç kız, tıpkı herhangi genç erkek gibi, icabında ailesinin yaşamasına medar olabilecek bir mesleğe sahip olmalıdır. Ailenin müşterek banileri, millet ve insaniyetin kurucuları sıfatı ile aile teşkil etmeğe karar veren çift ,mutlak aile hakkında muayyen bir kanat ve imana sahip olmalıdır. Ailenin yaşamasından erkek ne kadar her bakımdan mesul ise kadının da o kadar mesul olması gerekir. Halide Edib Adıvar genç kızlara şu şekilde nasihat eder: "Bugün altınıza çift otomobil çeken koca, yarın bir kaza veya kader neticesinde bir hasta, bir alil, bir züğürt olabilir. Böyle bir vaziyet hasıl olunca kadının ilk işi kocasının anası, babası, hâmisi, bakıcısı hatta hayatını temin eden bir menba olmaktır. Bunu her hanım kız evlenirken bilmeli "samanlık seyran olur" devri geçince ailenin müsavi surette, icap ederse tek başına mesul reisi olduğunu idrâk etmelidir. Lüzumu anında mesuliyet, kafa salâbeti, sağduyu ve selim fikre dayanan içtimaî ve ahlâkî kıymetleri hanım kızlara mutlak ve mutlak telkin etmek lâzımdır. Kadının bazı insanî zaaflarını, erkeklerin zaafları kadar affetmek mümkündür. Fakat daha zengin bir koca buldum diye, çocuğunu çoluğunu bırakıp kaçan kadın, aynı sahada aynı zaafı herhangi sebeble gösteren erkek kadar çirkin ve miskindir..Tırnak boyası ve dudak boyası, saç tuvaleti meselesi de, gene çok ölçüye, zevke bağlanması icap eden şeylerdir. Bütün bunlar, kendinizin ve ailenizin gıdasından kesmeğe mütevakkıf ise boyasız tırnağı ve dudağı moda yapmak sizin elinizdedir..Erkekler ne derlerse desinler, bu toprakların sahibi, yurdun manevî nazımı, milletin anaları sizlersiniz. Eğer maddî inkişafınızı bozmaksızın, maddî medeniyete muzavi bir de manevî ve ahlâkî bir nizamın tesisi, bugünün dünyasının tek kurtarıcı gayesi olduğunu idrâk eder ve onu ileride yavrularınıza aşılayabilirseniz, her zaman ve her halde çökmiyecek bir millet olarak kalmamızı temin etmiş olursunuz. Size son sözümle beraber, milletin kuvvetini, istikabele imanını muhafaza için elzem olan bir şeyi söylemek isterim. Daima istikbale inanın, daima keyfinizi muhafaza edin, maddî ve manevî bakımdan gözlerimizi ve gönüllerimizi açın! Göreceksiniz ki imanını muhafaza eden, tehlike karşısında gözü yılmayan kadınlara sahip olan millet, yalnız kendisi için değil, komşuları hatta dünya için en büyük ve daimî bir kuvvettir!"’13

Dergi yazarlarından Vedat Nedim Tör Evlilik Sanatı adlı yazısında, aile muvazenesinin sarsıldığından ve bir yastıkta kocayan çiftlerin sayısının giderek azaldığından bahseder. Tör'e göre din ahlâk ve hukukuna dayanan orta-çağ tipi ailede kocanın diktatörlüğünden kuvvet alan bir korku düzeni kolayca kurulabiliyordu. Fakat laik ahlâk ve hukukuna dayanan bugünün ailesinde, kadınla erkek arasında demokratik bir eşitlik tanındığı içindir ki, aile içinde muvazeneyi kurmak ve

13 Halide Edip Adıvar, "Genç Kızlarla Sohbet”, Aile Ev Dergisi, sayı 6, 1948, s.4-6. 
bozmadan devam ettirmek çok ince bir hüner halini almıştır. Bugün birçok Türk aileleri muvazenesi sık sık bozulan bir düzensizlik içinde iseler, bunun başlıca sebebini, gençlerin evlilik hayatına aile kurmak sanatının tamamıyla yabancıs1, âdeta gözleri bağlı olarak katılmalarında aramalıyız. Birçok genç kız, evlilik hayatına intibak edemiyorlar. Baba evinden ayrılınca denizden çıkmış balık gibi bocalıyorlar. Ev idaresinin tamamıla cahili olarak yeni yuvalarına giriyorlar. Yemek pişirmesini, dikiş dikmesini, ekonomik alışveriş yapmasını, hesap tutmasını, elbiselere, möbleye, erzaka bakmasını, haşeratla mücadele usullerini, leke çıkartmasını, evi zevkle döşeyip dayamasını, vazoya çiçek koymasını, duvara tablo asmasını, çocukları terbiye etmesini, kısaca iyi bir ev kadınının ve annenin bilmesi lazım gelen şeyleri hemen hemen hiçbirini bilmiyorlar. Kocasını kendisinden ve yuvasından bıktırmamak, daima yeni ve taze kalabilmek, daima keşfolunacak yeni bir tarafını saklamak, tatlı dilin ve güler yüzün büyüsünü bilmek akıllı bir ev kadınının muvaffakiyet silahlarıdır. Çalışan kadınların çoğu da kocalarına karşı bir nevi maddi istiklâle sahip oldukları için kadınlıklarını unutuyorlar, kadın kalmasını bilmiyorlar. Katı ve haşin oluyorlar. Hâlbuki evin bütçesine yardım etmek kadına hiçbir üstünlük bahşetmez. Müşterek bir yükü paylaşmak erkeğin izzeti nefsini kırmak için bir hak vermez. Bu inceliği hazmedemeyen kadınlar kocalarını kendilerinden zorla uzaklaştırmaktadırlar. Delikanlıların en büyük kusurları da hayat arkadaşlarında yalnızca dişiyi görmeleridir. Vedat Nedim Tör erkek nesli yetiştirme ve evlilik siyaseti ile ilgili şu noktalara işaret eder: "Kadına karşı saygı duyan kadında cinsîden başka ulvî'yi, bedî̂'yi, arkadaş'ı, hemşire'yi ve anne'yi arayan bir erkek nesli yetiştirmeye muhtacız. Kadında yaratıcı hamlelerin kaynağını göremeyen, kadında sadece hayvanı arıyan erkekler hiçbir vakit iyi bir aile reisi olmak pâyesine de erişemeyeceklerdir... Bazen sokakta kadınla karşı karşıya gelen erkeği görünce ç̧ok kere erkekliğimden utanıyorum. O bakışlardaki yapışıklılık ve sırnaşıklık ve ille o sesin tonundaki hoyratlık ve adîlik mukkaddes aile müessesesinin yarını için cesaret verici alâmetler değildir. Cins terbiyesinin en iyi vasıtası güzel sanatlardır. Gençliğimizin ruhunu sistemli bir sanat terbiyesinin haddesinden geçirerek inceltmek, yumuşatmak ve yükseltmek zorundayı. Delikanlılarımız da tıpkı kızlarımız gibi hiçbir şeye merak sarmasını öğrenmeden yetişiyorlar. Onun için evlendikleri zaman karıları ile yalnız kalınca canları sıkılıyor. Karı koca arasında söylenecek söz bitince oyalanacak bir şey bulamıyorlar. Hâlbuki Amerikalıların "Hobi” dedikleri bir şeye merak sardırmak alışkanlığını çocuklarımıza tâ ilkokuldan verebilsek, kendini mesut hissetmenin sırrını da onlara öğretmiş olacağız... Onun için günümüzün ileri terbiye metodları Hobilere çok önem veriyor ve okullarda Hobi kulüpleri kurarak çocuklara oyun şevki içinde onların iyi vatandaş, iyi koca, iyi karı, iyi baba, iyi anne ve iyi insan olmalarını 
sağlayacak bir takım itiyatlar ve ahlâklar kazandırıyor. Sağlam bir iş terbiyesi, irade terbiyesi ve sanat terbiyesi almış gençlerin kuracakları ailelerde karı koca arasında daima sayg1 ve sevgi hisleri hakim olacak, birbirlerine karşı tatlı dilli, güler yüzlü, müsamahalı ve anlayışlı davranacaklar, işten yüksünmeyecekler, talihlerinden boyuna şikayet ederek hayatı birbirlerine zehir etmeyecekler, koltuğa yaslanıp güzel kitaplar okumanın büyük tesellisini bilecekler, Hobilerle oyalanıp birbirlerini yemeyecekler, çocuk yetiştirme sanatının inceliklerini bilerek iyi ve faydalı vatandaşlar büyütmenin zevkini ve şerefini tadacaklar, kısaca uzun ömürlü aileler içinde bahtiyar yaşamanın sırrına erecekler." ${ }^{14}$

Yine Vedat Nedim Tör Evli Kalabilmek adlı yazısında evlenmek isteyen gençlerin önceden sıhhî muayeneye tâbi tutulmasını ailenin maddi ve manevi sağlığını korumaya yönelik faydalı zaruretlerden biri olarak görür. Tör'e göre gençlerin gözü kapalı evlenmeye kalkışmaları tam manasıyla içtimaî israftır. Toy gençler çok kere vücutların cazibesini aynı zamanda ruhların da kaynaşması mânasında alıyorlar. Hâlbuki zamanla, vücutlar birbirine alışıp da sırlarını ve büyülerini kaybedince ruhlardaki aykırılıklar dayanılmaz bir işkence halini alıyor ve böylelikle aile de çözülüp dağılıyor. Hâlbuki vücutlar arasında olduğu kadar ruhlar, huylar, alâkalar arasındaki ahenk de ailenin sürekli bir varlık taşıyabilmesi için şarttır. Birçok memleketlerde kurulan "Evlenme danışma büroları" da talihlerini birleştirmek isteyen gençlerin ruhî ve içtimaî yapılarını, manevi yapılarını tıpkı bir laboratuarda kan, tükürük ve idrar muayene eder gibi bir takım ince araştırmalardan geçirerek teşhislerini koyuyorlar. Tör, yazısında ayrıca evlenme danışma bürolarının şarlatanlığa, şantaja ve skandallara çok müsait olduğunu, danışma bürolarının ilmî otoritesi olan gayet dürüst kimseler tarafından kurulmaları ve devlet tarafindan kontrol edilmeleri gerektiğini dile getirir. Evlenmedeki talih ve tesadüflerin payını mümkün olduğu kadar azaltarak, aile müessesesinin daha sağlam temeller üzerinde kurulmasının imkânlarının araştırılmasının elzem olduğunu savunur. ${ }^{15}$

\section{Çocuk Mevzusu ve Siyaseti}

Aile dergisinde çocuk ile ilgili pedagojik yazılar, nasihatler Ailede Çocuk köşesinde yer almaktadır. Bu yazıların büyük kısmını yabancı süreli yayınlardan yapılan tercümeler oluşturmaktadır. Ailede Çocuk köşesinde yer alan bu yazıların ilkinde Çocuk Büyütmek Sanatı anlatılır. Okuyuculara, çocuk büyütmenin bir sanâtkar ustalığı isteyen yaratıcı bir çalışma olduğu aktarılır. Annelik vazifelerini

14 Vedat Nedim Tör, "Evlilik Sanatı”, Aile Ev Dergisi, say1 6 ,1948, s. 13-6.

15 Vedat Nedim Tör, "Evli Kalabilmek”, Aile Ev Dergisi, say1 9, 1949, s. 3. 
görürken bir imtihandan geçildiğinden ve bu imtihandan başarılı bir şekilde çıkmanın yollarından söz edilir. Bir çocuk yetiştirmenin mesuliyetini hiç bir kaçamak yol aramaksızın yüklenildiği andan itibaren, çocuğa annenin yapabileceği şeyleri vaadetmesi gerektiği nasihat edilir. Böylece çocuğun ilk yaşlarda annesinin kudretine ve söylediğini yapan bir insan olduğuna inanmasının sağlanacağına ve çocuğun da böyle olmaya imreneceğine dikkat çekilir. Bu yazıda, çocuğun zevkleri ile duygularına tesir etmeye kalkışılmaması, çocuğun yalnız komşulardan değil, mektepten de arkadaş edinmeye teşvik edilmesi gerektiği vurgulanır ${ }^{16}$. Aynı köşede Siz ve Çocuklarınız adlı yazı son zamanlarda adet olduğu üzere annelerle babaların çocuklarını ancak yemek yedirirken, yıkanırken ve altı değiştirirken dokunabilecekleri, kolay kırılıp dökülür bir mahluk yerine koymaya başladıklarından söz eder. Lüzumlu anlardan başka zaman çocuğun kucağa alınmasına, ellenmesine katiyyen müsaade etmediklerini belirtir. İfrata kaçmamak ve boyuna elde kucakta dolaştırmamak şartıyla çocuğu kucağa almanın, okşamanın, beşikte yatırırken yorganını düzeltmenin bir sakıncası olmadığını aktarır. Yazı, çocuk yetiştirirken yapılan hatalardan veya fena âdetlerden birinin de çocuğu doktor ile korkutmak olduğunu işler. Çocuğu aldatarak doktora götürmenin katiyyen doğru bir davranış olmadığını izah eder. Ayrıca, çocuğun her şeyden önce sevilmek istediğini ve çocuğun annesine ihtiyacı varken ev işlerinin ehemmiyetli olmad1ğını, ev işinin başka bir zaman da görülebileceğinin fakat çocuğun istediği zaman dinlenilmediğinde, başka şeylere kendisinden daha fazla ehemmiyet verildiğine inanacağını ve yavaş yavaş kendi meselelerini ailesine açmaktan vazgeçeceğini vurgular. ${ }^{17}$

Ailede Çocuk köşesinde çocuk hastalanınca nelere dikkat edilmesi gerektiği, ilk çocuğun ikinciyi kıskanmaması, çocuğun iştahsızlığını ve çocukta anne babay1 telaşlaştıran itiyatları gidermek için neler yapılması gerektiği ile ilgili öğütlere yer verilir. Ayrıca karı koca ayrılıklarında çocukları müşkül duruma düşüren noktalara işaret edilir. Anne ve babalar çocukları lüzumsuz korkulara kaptırmamaları, muntazam olmaya alıştırmaları ve okuldaki başarıları için neler yapmaları gerektiği konusunda aydınlatılır. Dayağın bir terbiye vasıtası olmadığı söylenir. Ana babaların disiplini, çocuğu kendilerine itaat ettirmek için yahut çocuklarının uslu durması için bir vasıta olarak düşündükleri ifade edilir. Disiplinin ne ceza ne de itaat vasıtası olmadığı, disiplinin gayesinin kendine güvenen çocuklar yetiştirmek olduğu ileri sürülür. Çocuğa nasıl iyi bir anne ve baba olunabileceğinin usulleri anlat1lir.

16 Aile Ev Dergisi, “Çocuk Büyütme Sanatı”, Aile Ev Dergisi, sayı 2, 1947,s. 25-6.

17 Aile Ev Dergisi, "Siz ve Çocuklarınız”, Aile Ev Dergisi, sayı 2, 1947, s. 29. 
Şevket Rado, Aile Terbiyesi yazısında çocuğun hamurunun veya terbiyesinin evde yoğrulduğundan bahseder. Rado’ya göre her ailenin başlica endişesi çocuklarını iyi yetiştirmektir. Aileler çocuklarının iyi yetişmesi için onları iyi mekteplerde okutmanın yeterli olduğunu zanneder. Terbiyecilerin birçok müşahedelerden sonra edindikleri kanaate göre iyi geçinmeyen, s1k s1k kavga eden, birbirlerini daima kıran ana babanın halleri çocuklar üzerinde ağır tesirler bırakmakta ve çocukların karakter tohumları bu yaşlarda iken atılmaktadır. Edinilmiş huysuzlukları mektepte verilecek terbiye ile değiştirmek hemen hemen imkânsız gibidir. $^{18}$

Çocuk ve Yarını ${ }^{19}$ adlı bir başka yazıda çocuk terbiyesinde en önemli kusurlardan biri ebeveynin zaafı ve lüzumsuz yerlerde gösterdiği müsamahalara değinilir. Yarına korkusuzca bakan, hayat mücadelesinde yalnızca kendine güvenen çocuğun aile disiplini içinde büyümüş çocuk olduğundan söz edilir. Büyüklerin iradesine inanan, sayg1 gösteren, bu iradeyi ne ağlama ve sızlamanın ne de şımarıklığın sarsamayacağına emin olan çocuğun ileride kendisinin de kuvvetli bir irade sahibi olacağı ve hayat yolunda kolay kolay sendelemeyeceği aktarılır.

Dergide çocuğun yetişmesinde oyunun ve oyuncağın önemi üzerinde durulur. Doğan Kardeş, Bu Toprağın Masalları gibi temiz hüviyetli çocuk neşriyatı müstesna olmak şartıyla, çocuk dergilerinin sahifelerinin barut koktuğuna, çocuk romanlarından kan fişkırdığına, çocuk neslinin taze beyninde Tarzan çığlığı, tabanca sesi, haydut islığ 1 ve gangaster parolasının uğuldadığına dikkat çekilir. Ebeveynler çocuk nesline tesir eden haydut edebiyatı konusunda ikaz edilir. Vedat Nedim Tör, çocuk neslinin terbiye edilmesinde ve yetiştirilmesinde kaliteli kitabın önemini Çocukların Hakkı yazısında şu sözler ile dile getirir "Beyoğlundaki kitapçılara her uğradığımda gözlerim başka milletlerin kendi çocukları için hazırladıkları kitaplara kayar. İster İngilizce ister Almanca ister Fransızca olsun bütün medenî milletlerin çocuklarına verdikleri kitapların 1. gayet dayanıklı, karton kapakl1, 2. Beyaz ve tok kağıtl1, 3. İyi ve temiz baskı11, 4. Güzel resimli ve çok kere renkli, 5. Kenarları kesilmiş olduklarını görerek adeta kıskanırım. Çocuk kitaplarına gösterilen bu itinanın, titizliğin sebepleri üzerine düşüncelere dalarım. $\mathrm{Bu}$ vasıfları taşıyan kitap, çocuğa 1. Saygı telkin eder, onu hor kullanmamay1, iyi saklamayı öğretir. Çocukta küçük yaştan bakım zihniyetinin yerleşmesini sağlar. 2. Çocukta güzel şeyleri aramak, güzel şeyleri sevmek ihtiyacını doğurur. 3. Böyle kitaplarla yetişen çocuklar temizliği, intizamı severler. 4. Ana diline karşı sevgi ve saygı duyarlar. 5. Okumak, öğrenmek itiyadı kökleşir. Kısaca, kaliteli

18 Şevket Rado, "Aile Terbiyesi”, Aile Ev Dergisi, say1 17, 1951, s.3.

19 Aile Ev Dergisi,“Çocuk ve Yarını”, Aile Ev Dergisi, sayı 20, 1952, s. 65-6. 
kitap, iyi vatandaşlar ve iyi insanlar yetiştirmek için en mükemmel bir terbiye vasitasidır." 20

Adile Ayda Çocuk Yayınları yazısında insanın ahlâkî ve fikrî inkişafında, karakterinin teşekkülünde irsî temayüllerin hissesi olmakla birlikte en büyük rolü muhitin etkisi olduğunu belirtir. Ayda'ya göre iptidaî cemiyetlerde muhitin tesiri sadece görme ve işitme yolu ile kendini gösterir. Mütekâmil ve medenî cemiyetlerde ise görme ve işitmenin yanında bir de okuma vardır. Yani fert muhitinin tesirine ayrıca okuyup öğrendikleri vasitasıyla da maruz kalır. Gazetelerin, mecmuaların, kitapların sahifeleri arasından okuyucuların ruhları üzerine bir ahtopot kolları gibi uzanan bir takım kollar vardır. Bunlar hemen hemen daima okşayıcı, çok defa yapıcı, fakat bazen de tahrip edicidir. İlköğretimin mecburi olduğu her memlekette olduğu gibi bizde de çocuklar beş veya altı yaşlarından itibaren bu kolların keyfine terk ve teslim ediliyor. Çocuk tarafından okunan şeyler, kitap, dergi vs. en kuvvetli birer terbiye vasıtasıdır. Fakat burada unutulmaması lâzım olan şudur ki emir, nasihat ve tavsiye mahiyetinde yazıların çocuk üzerindeki tesiri cüzîdir. Çocuğu da insanı da olgunlaştıran aldığı nasihatler değil, yaşadığ 1 tecrübelerdir. Çocuğu okumaya sevk eden gayelerden biri "adam olma" diğeri ise "dünyayı tanıma"dır. Cumhuriyet devrinin ilk zamanlarında en çok ihmal edilmiş olan meselelerden biri de çocuk edebiyatı, çocuk neşriyatı meselesidir. Senelerce Türk çocuğu yaş seviyesine göre okuyacak bir şey bulamamış, kendisinde hissettiği ruhî gıda ihtiyacını büyüklerin kitabı ile tatmin etmiştir. Ancak İkinci Cihan Harbinden sonradır ki çocuk yayınları işi münevver ve insaflı ellere geçmiş ve ihtiyaca cevap verecek yolda hakiki faaliyet göze çarpmağa başlamıştır. ${ }^{21}$

\section{Yaşama Mevzusu ve Siyaseti}

Aile dergisi hedef kitlesine yaşamı tesadüflere bırakılmaması, üzerinde etraflıca düşünülmesi ve medenî kaideler, ölçüler çerçevesinde titiz bir şekilde sürekli yeniden imal edilmesi gereken süreç olarak sunar. Okuyuculara yaşam ve yaşama saadetinin ne olduğu ile ilgili çeşitli tanımları, ilkeleri takdim eder. Yaşam ile ilgili çeşitli öğütler verir. Vedat Nedim Tör, Acep Saadet Ne Ola Ki? yazısında, saadetin para ile pulla satın alınabilecek bir matah haline gelmediğini söyler. Ona göre saadetin değeri, nadir oluşundan ziyade, onu herkesin kendi zevkine ve ölçüsüne göre yaratabilmesindedir. Kişinin saadeti kendi eseridir. Her sanatkâr kendi eserini nasıl severse, herkes de kendi saadetine öylece bağlıdır. Severek yaşam saadetine ulaşabilir. Sevginin rahmetini içinde duymayan insan için hayat

20 Vedat Nedim Tör,. "Çocukların Hakkı", Aile Ev Dergisi,: sayı 8, 1949, s.14

21 Adile Ayda, "Çocuk Yayınları”, Aile Ev Dergisi, sayı 18, 1951, s.15-9. 
gerçekten bir azaptır. Sevgi sarf edildikçe çoğalır ve hiçbir vakit israf edilmiş sayılmaz. Sevgilerini bir cimrinin para sarf etmesi gibi yürekleri oynayarak ve elleri titreyerek harcayanlar hiçbir vakit sevgi biriktiremezler. Hayat, neşe ve şevk ancak sevginin toprağında gelişir. Sevgi bütün yaratıcı faaliyetlerin mayasıdır. Sanatkâr severek yaratır. Bilgin severek araştırır. Devlet adamı severse başarır. Sevgi birleştirip toplar. Nefret ve kin parçalayıp dağıtır. Sevgi müsbet ve yapıc1dır; nefret menfi ve yıkıcıdır. Saadet daima müsbet olanındır. Cemiyete faydalı olmanın zevkini unutmuş insanlar, kalabalık ortasında bencil yalnızlığıyla yaşayan insanlar hayatlarından hiçbir vakit mutlu olamayacaklar, daima bezip şikâyet edecekler, daima kara talihlerinden dem vuracaklar ve böylece kısacık ömürlerini hem kendilerine hem de başkalarına zehir edeceklerdir. ${ }^{22}$

Vedat Nedim Tör, Canı Sikılan İnsan yazısıyla aile dergisi okuyucularına can sıkıntısının özelliklerini anlatır. Tör'e göre, can sıkıntısı bahtsızlıkların şahıdır. Kahveleri çoklukla canı sıkılanlar doldurur. Kumar, canı sıkılanların oyunu, dedikodu canı sıkılanların sporudur. Ayyaşlar ordusuna can sıkıntısı kumanda eder. Sinir buhranlarının sütninesi can sıkıntısıdır. Avare, tufeyli, menfi, laf ebesi, gammaz hep can sıkıntısının piçleridir. Can sıkıntısının babası işsizliktir. Bir işe gönül vermemiş olan, elinden severek yapacağ 1 bir iş gelmeyen, bir kitapta, bir elişinde, bir musiki aletinde, bir bahçe köşesinde, bir radyoda yahut sadece kapalı gözler ile bir hayal etmede can sıkıntısını gideren en büyük tılsımı bulamayan insanlar herhangi bir davaya bağlanıp cemiyete faydalı olmanın zevkini tadamazlar. Canı sıkılan insanlar çabucak ihtiyarlar. Onların yüzünde, yaşama zevkinin rahat ve aydınlık diriliği yoktur. İçlerine kurt düşmüş möbleler gibi boyuna kemirilip dururlar. Bezgin bir donukluk gözlerinin ferini örter. Dudakları daima sıkış1k ve aşağı doğru sarkıktır. Şom ağızlıdırlar. Her zaman fenalıktan, kötülükten dem vururlar. Bu insanların ruhuna İyi'nin ve Güzel'in rahmeti yağmaz. ${ }^{23}$

Burhan Toprak "Ballar Balını Buldum Koğanım Yağma Olsun"24 yazısında temizin lekeliden, sağlamın çürük olandan, kuvvetlinin sıskadan, inananın ve mesut olanın, imansızdan daha güzel ve asîl olduğuna değinir. Hakikate kavuşanın en büyük dostu bulduğunu ileri sürer. Toprak'a göre kaderin seni ezmez, yalnız sen kendini ezersin, kendini yenmekten daha büyük savaş yoktur. Hayatı kaybetmekten daha acı bir şey vardır. O da yaşamanın mânasını kaybetmektir. Her dakikası muazzam neticeler verecek insan hayatı, baştan aşağıya ciddiye alınmalıdır.

22 Vedat Nedim Tör, “Acep Saadet Ne Ola Ki?”, Aile Ev Dergisi, sayı 1, 1947, s. 21.

23 Vedat Nedim Tör. "Canı Sıkılan İnsan”, Aile Ev Dergisi, sayı 2, 1947, s. 55.

24 Burhan Toprak, "Ballar Balını Buldum Koğanım Yağma Olsun”, Aile Ev Dergisi, sayı 3, 1947, s.12-3. 
1947 yılının üçüncü sayısında Vedat Nedim Tör, Açık Hava Tiyatrosu yazısı ile aile okuyucularına "mideleri aç insanlardan korkma, fakat kafaları boş, ruhları çorak insanlardan kork" diye seslenir. Tör, dergi okuyucularına tiyatro binalarını, konser ve sergi evlerini, kısaca geniş halk yığınlarının ruh sağlığını koruyacak kültür müesseselerini lüzumsuz, yersiz birer israf sayan iptidai görüşün kandırıcı ve demagojik tesirlerine kendini kaptırmamasını öğütler. Ruhu ve kafası sağlam olmayan insanların vücutlarının da sağlam olmayacağını ileri sürer. Vücudu koruyabilmek için her şeyden önce kafayı kurtarmanın gerekli olduğunu söyler. Ona göre kafası sağlam olmayan insan, vücudunun kıymetini bilmez. Hastalıklar geri cemiyetlerde en çok kurban verir. Çünkü sağlık maddi değil, manevi bir kıymettir. Manevi kıymetleri koruyabilmek içinse manevi seviyenin yükselmesi şarttır. İşte bu israf saydığımız, hor görüp alaya aldığımız tiyatro binaları, sergi sarayları ve konser evleri sayesindedir ki, milletler ruhlarını ve vücutlarını bakımsızlığın esaretinden kurtarabilirler. ${ }^{25}$

Dergi İyi Konuşma Sanat ${ }^{26}$ adlı yazıyla gündelik hayatta konuşurken nelere dikkate edilmesi gerektiği konusunda okuyucularına çeşitli öğütler verir. Yazıya göre konuşurken sırf kendinizden bahsetmekten kaçınınız. Karşınızdakine sıhhatinizden uzun uzadıya bahsetmeyiniz. Müşküllerinizi anlatırken kısa kesiniz. Hep siz konuşmayınız başkalarına da konuşma firsatı veriniz. Karşınızdakinin fikrini derhal yıkmaya kalkmayınız. Aynı fikirde olmasanız bile karşınızdakinin düşüncesine birdenbire hücum etmeyiniz. Önce uyuştuğunuz noktaları ileri sürüp anlaşmadığınız tarafları sonra belirtmeyi tercih ediniz. Konuşan birinin sözünü kesmeyiniz. Birdenbire mevzu değiştirmeyiniz. Karşınızdakinin sözlerini alâka ile dinleyin. Yıkıcı konuşmalardan sakının. Lüzumsuz tenkitlerden kaçının.

Vedat Nedim Tör, Caz Hayranlığg yazısında kötünün yayılma ve tutunma kabiliyetinden bahseder. Amerikan medeniyetinin iyi ve güzel taraflarından ziyade bayağ 1 ve pespaye taraflarının bir virüs sinsiliğiyle yaşama yayıldığından söz eder. "Çocuklarımız iki eli tabancalı, suratı maskeli haydut edebiyatıyla mest oluyorlar. Gençlerimiz o galiz, çarpık ve bozuk ahenkli caz musikisinin hayranlığ içinde kendilerinden geçiyorlar. Dövüş, vuruş, kabalık ve hoyratlık heyecanını sömüren gangester filmlerinin kahramanlarını üstün-insan örnekleri olarak yayıp durmaktayız. Biricik çocuk tiyatromuzda Holivut hayranlığ1 telkin olunuyor. Radyolarımız durmadan caz musikisinin yayılmasına hizmet ediyor. Üstelik bu musikinin bir kafa ve zekâ musikisi olduğunu ispata çalışan konferanslar veriliyor! Amerikan medeniyetinin yüksek ve ileri eserlerinden faydalanmak yalnız

25 Vedat Nedim Tör,“Açık Hava Tiyatrosu”, Aile Ev Dergisi,: sayı 3: 1947, s. 15.

26 Aile Ev Dergisi, "İyi Konuşma Sanatı”, Aile Ev Dergisi, say1 9: 1949, s. 59-60 
akıl harcıdır. Fakat hiçbir değer taşımayan kültür ve sanat mallarına karşı bu uluorta "teslimiyet", bu ayırt etme ve seçme kabiliyetinden mahrumiyet doğrusu hazindir. Amerika' da bile gittikçe artan bir hoşnutsuzlukla karşılanan bu gibi kültür ve sanat dışı yayınlara gümrük kapılarımızda biraz daha az "misafirperver" davranmanın zamanı her halde gelmiştir." ${ }^{27}$

Aile dergisinin 18. sayısında yer alan En Büyük Dostumuz Zaman ${ }^{28}$ adlı yazı herkesin zamanı düşman gibi gördüğünden özellikle de kadınların zamana kem gözle baktıklarından söz eder. Yazıya göre hakikatte zaman bizim düşmanımız değil dostumuzdur. Istıraplarımızın en iyi devası odur. Omuzlarımızdaki ezici yükü kaldıran, hayatımızdaki aşılması çetin yolları düpedüz eden yine odur. Kadınlara gelince onlar için de zaman sandıklarından çok daha iyidir. Eğer onunla geçinmeyi bilirlerse zaman onların hasmı değil en vefakâr dostudur. Zaman kadınların güzelliklerini alıp götürse de onlara ebediyen kaybolmayan bir cazibe bağışlar. Zaman ve tecrübenin olgunlaştırdığg, mükemmelleştirdiği kadındaki füsun kimde bulunur? İlerleyen seneler bir ok kadına sahip olmadıkları güzellikleri bağışlar. Zaman bazı genç kızların vücutlarındaki biçimsiz çizgileri işleyen bir heykeltraş gibi çalışır. Zaman bizim bütün zorluklarımızı halleder, yeter ki ona bağlanmayı bilelim. Zaman bize kuvvet verir, bize bir şey hissettirmeden güçlüklerimizin yükünü hafifletir. Yavaş yavaş bize onları taşıyacak kuvveti verir. Zamanın bize en büyük bağışlarından biri de kötü hatıralarımızı unutturmasıdır. Zamanın bize en büyük dostluklarından biri de sulh ve sükûn sağlamasıdır. Zaman, en eski kin ve garazın bile kıvılcımlarını söndürür. Bize kötülük etmiş olanları, aldatmış ve ihanet etmiş kimseleri affettirir.

\section{Sonuç}

Bu yazıda 1947-1952 yılları arasında aile, evlilik, kadınlık, çocukluk ve yaşam hakkında kamusal metin üreten Aile Ev Dergisine bakılmıştır. Bu dergideki yazılar, dönemin biyopolitik kaideleri ve mücadeleleri hakkında önemli noktalara dikkat çekmektedir. Didaktik, pedagojik bir üslupla okuyucularına modern hayat tarzı hakkında nasihatler vermektedir. Türkiye'de yurttaşların sahip olması gereken biyopolitik vasıflara işaret etmektedir.

27 Vedat Nedim Tör. "Caz Hayranlığı”, Aile Ev Dergisi, sayı 12, 1950, s. 77.

28 Aile Ev Dergisi.,"En Büyük Dostumuz Zaman”, Aile Ev Dergisi, say1 18, 1949, s. 23-4. 


\section{Kaynakça}

Adıvar, Halide Edip, “Genç Kızlarla Sohbet”, Aile Ev Dergisi, sayı 6, 1948.

Agamben, Giorgio, Kutsal Insan: Egemen İktidar ve Çıplak Hayat, çev. İ. Türkmen, İstanbul, Ayrıntı Yayınları, 2001.

Aile Ev Dergisi. “Çocuk Büyütme Sanatı”, Aile Ev Dergisi, sayı 2, 1947.

, “Siz ve Çocuklarınız”, Aile Ev Dergisi, sayı 2, 1947.

, “Eşref Saatini Kollayınız”, Aile Ev Dergisi, sayı 2, 1947.

, “İyi Konuşma Sanatı”, Aile Ev Dergisi, sayı 9, 1949.

, “En Büyük Dostumuz Zaman”, Aile Ev Dergisi, sayı 18, 1949.

, “Çocuk ve Yarını”, Aile Ev Dergisi, sayı 20, 1952.

Aksel, İhsan Şükrü, “Evde Sinir Muvazenesi”, Aile Ev Dergisi, sayı 2, 1947.

Ayda, Adile, “Çocuk Yayınları”, Aile Ev Dergisi, sayı 18, 1951.

Foucault, Michel, Cinselliğin Tarihi, çev. H. U. Tanrı̈̈ver, İstanbul, Ayrıntı Yayınlar1, 2012.

Kazancıgil, Tevfik Remzi, "Kadın Hayatının Altı Merhalesi”, Aile Ev Dergisi, say1 3, 1947.

Kessler, Gerhard, “Aile Siyaseti”, Aile Ev Dergisi, say1 4, 1948.

Lemke, Thomas, Biyopolitika, çev. U. Özmakas, İstanbul, İletişim Yayınları, 2013.

Neumark, F., “Mesken Meselesi ve Aile”, Aile Ev Dergisi, say1 4, 1948.

Nureddin, Vâlâ, "Mesleğiniz Dışında Neye Merakınız Var ?”, Aile Ev Dergisi, say1 2, 1947.

, “Ailenin Röportajları: Kar1-Koca Geçimsizliğinin Tedavisi Mümkün Müdür?”, Aile Ev Dergisi, say1 3, 1947.

Rado, Şevket, “Ayıran ve Birleştiren Kitap”, Aile Ev Dergisi, sayı 5, 1948. , “Aile Terbiyesi”, Aile Ev Dergisi, say1 17, 1951.

Toprak, Burhan, "Ballar Balını Buldum Koğanım Yağma Olsun”, Aile Ev Dergisi, say1 3, 1947.

Tör, Vedat Nedim, “Aileyi Kurarken”, Aile Ev Dergisi, sayı 1, 1947.

, “Acep Saadet Ne Ola Ki?”, Aile Ev Dergisi, say1 1, 1947.

, “Canı S1k1lan İnsan”, Aile Ev Dergisi, say1 2, 1947. 
, "Açık Hava Tiyatrosu”, Aile Ev Dergisi, sayı 3, 1947.

, "Evlilik Sanatı", Aile Ev Dergisi, say1 6, 1948.

, “Çocukların Hakkı", Aile Ev Dergisi, sayı 8, 1949.

, “Evli Kalabilmek”, Aile Ev Dergisi, sayı 9, 1949.

, "Okuyan Aile”, Aile Ev Dergisi, say1 10, 1949.

, “Caz Hayranlı̆̆ı”, Aile Ev Dergisi, sayı 12, 1950.

Tunç, Mustafa Şekip, "Eski Aileden Yeni Aileye", Aile Ev Dergisi, say1 1, 1947. 